\title{
REVIEW
}

\section{Eric Nelson \\ The Hebrew Republic: Jewish Sources and the Transformation of European Political Thought}

(Cambridge MA: Harvard University Press, 2010), hardcover, 229 pp.

Diego Lucci, American University in Bulgaria

This book by Eric Nelson, Professor of Government at Harvard University, is a significant contribution to the current debate on the use of Jewish sources in early modern political thought, particularly in the republican currents of the 17th century. According to Nelson, while Renaissance humanists concentrated on the pagan inheritance of Greek and Roman antiquity, "in the seventeenth century, in the full fervor of the Reformation, ...political theology reentered the mainstream of European intellectual life. The Protestant summons to return to the Biblical text brought with it incessant appeals to God's constitutional preferences as embodied in Scripture.... During this period, Christians began to regard the Hebrew Bible as a political constitution, designed by God himself for the children of Israel. They also came to see the full array of newly available rabbinical texts as authoritative guides to the institutions and practices of this perfect republic" (pp. 2-3). Nelson thus examines the origins of some central ideas of modern political thought, generated "not as a by-product of advancing secularization, but rather out of the deeply theologized context of the Biblical century" (p. 3). In fact, in the 16th and 17th centuries the Hebrew Bible, the Talmud, and several rabbinic writings were printed and made available in their original language to Christian scholars. Moreover, Hebrew masterpieces such as the Zohar, the Targums, numerous Midrashic commentaries, several Talmudic treatises, and the works of Maimonides and other major Jewish thinkers were translated into Latin. The Hebrew revival hence contributed to transforming "European literature and criticism, medicine and science, theology and ecclesiology, and philosophy and law" (p. 16). However, Nelson's book "is concerned with one aspect of the phenomenon in particular: its intersection with political thought" (p. 16).

The first chapter of the book deals with the rise of republican exclusivism. Nelson points out that, until the Renaissance, "republicanism was always a relative position...characterized by the claim that republics are better than monarchies" (p. 23). It was in the 17th century that the idea that republics are the only legitimate regimes emerged and spread, particularly among English Puritan intellectuals. Nelson focuses especially on the use that John Milton made of rabbinic materials to infer that the state established by Moses was a republic and that "monarchy is itself a sin; it is everywhere and always the act of bowing down to flesh and blood instead of God, and is therefore tantamount to idolatry" (p. 37). In fact, Milton's position, which strongly influenced other English republican thinkers, such as James Harrington and Algernon Sidney, was based on a combined reading of Deuteronomy (especially chapter 17), the First Book of Samuel (particularly chapter 8), and the Midrashic commentary on Deuteronomy.

Another modern political concept dating back to the 17th century is that of wealth redistribution, which is examined in the second chapter of the volume. Nelson observes that the issue of redistribution resulted from the Renaissance rediscovery of the Roman agrarian laws, and the rise of theories of redistribution was furthered by the consideration of the biblical land laws. In fact, it 
was through the medium of rabbinic commentaries on the Torah that the Dutch scholar Petrus Cunaeus, author of De Republica Hebraeorum (1617), found a justification for land redistribution in the biblical text. Cunaeus' position in favor of redistribution was later adopted by Harrington and thus entered the debate on land and property in Puritan England. (I would add that the Puritan debate on redistribution was particularly acute because of the need to reward those who had served Parliament during Civil Wars.)

The third chapter deals with the theme of the Hebrew theocracy in the development of the early modern theories of religious toleration, particularly in the Erastian milieus of the Netherlands and the English Revolution. Erastianism is the theory that the state ought to have jurisdiction over religious matters. However, Erastian theorists disagreed among themselves about the degree to which the civil magistrate should regulate religious observance. Cunaeus played a crucial role in promoting a broad view of religious toleration, and he based his theory of toleration on an interpretation of the Torah as mediated by the Talmud and Maimonides. To the Dutch Hebraist, not only the Gentiles who lived in the "Hebrew republic," but also the Jews were bound by the Law to observe only principles necessary for establishing a political society and maintaining the civil peace. His position was later confirmed by the English Hebraist John Selden and especially by James Harrington, who, in The Commonwealth of Oceana (1656), highlighted the necessity of extensive religious freedom in the ideal political community.

Nelson's criticism against the mainstream narrative of the development of modern political thought explicitly targets Mark Lilla's, Jonathan Israel's, and the late Perez Zagorin's views of the rise of republicanism and toleration in the early modern era. Nelson challenges the idea that the modern concepts of toleration, liberty, equality, and justice emerged merely from a process of secularization, in which all appeals to a higher revelation came to be considered illegitimate and a separation between church and state was regarded as necessary. His analysis shows that the rise of republican exclusivism, redistribution theories, and religious toleration was strongly indebted to the "Hebrew revival" of the Biblical century. He therefore concludes his book with a brief analysis of Spinoza's and Locke's borrowings from 17th-century Erastianism in their works on the civil government and religious toleration.

The fact that Nelson's analysis of Spinoza's and Locke's ideas of government and toleration is very short, and hence partial, is the only significant flaw in this brilliant volume. Had Nelson offered a more complex assessment of Spinoza's and Locke's Erastian roots, and had he examined the reasons for the significant differences between those two influential authors' works and their Erastian sources, especially regarding Spinoza's view of philosophy and revealed religion and Locke's distinction between the spheres of politics and religion, he would have provided an even more convincing discussion of the idea that modern political thought resulted merely from a process of secularization. Moreover, Nelson presents an excellent analysis of the connections between the development of Christian Hebraism and the transformation of republican thought. However, as regards the origins and implications of the Christian interest in Jewish political traditions and sources, he concentrates especially on academic environments, and does not focus enough on the social and political contexts that contributed to, and were affected by, the intellectual phenomenon under consideration, particularly in the Netherlands, before and after the controversial Synod of Dordt, and in England at the time of the Puritan Revolution and the Commonwealth.

All the same, The Hebrew Republic is in many respects a groundbreaking volume. In fact, it presents a comprehensive and original analysis of a significant theme and opens new research perspectives. It would indeed be interesting to study the reciprocal influences between Christian and Jewish views of the Hebrew Republic in the 17th century, with special focus on Rabbi 
Simone Luzzatto's unorthodox interpretation of Mosaic Judaism as a political model inspired by "reason of state," already highlighted by historians Bernard Septimus, Abraham Melamed, and Benjamin Ravid. Another issue still to be examined is the impact that the 17th-century theories of the Hebrew Republic had on republican authors of the 18th century. (The only exception in this respect is the work of the freethinker John Toland, whose interpretation of Mosaic Judaism, strongly influenced by Cunaeus, Harrington, and Luzzatto, has been studied by several historians, most prominently by Justin Champion.)

The issue of the long-term impact of those 17th-century theories is relevant, more generally, to the evolution of Christian-Jewish relations in the context of the intellectual, cultural, and social dynamics that paved the way to the Age of Enlightenment. Nelson points out that his book focuses on "how European Christians in the sixteenth and seventeenth centuries interacted with a foreign corpus of political and theological writings. Although...Jews played an important role in the dissemination of the Hebrew texts with which this study is concerned, the political debates that these texts came to structure took place among Christians-Christians who, it must be said, had for the most part never met a Jew, and who were (again for the most part) anything but philo-semites" (p. 7). Though Nelson does not look to later periods, we should note that the Hebrew revival of the 17th century brought about the gradual emancipation of Jewish studies from the dominion of Christian theology. This process favored a rethinking of Judaism and Jewish history, and hence of the Jews' status in Christian Europe, that was largely uninfluenced by traditional, Christian, supersessionist views and concepts. This phenomenon had significant consequences in the Age of Enlightenment, as it led, on the one hand, to the debate on Jewish emancipation, and on the other, to the development of new, secular forms of anti-Jewish hostility. Nelson's intellectually lively and immensely erudite study can thus contribute also to the ongoing historiographical debate about the long-term cultural, social, and political implications of Christian engagement with Jewish thought in the early modern era-a subject on which such scholars as Ronald Schechter, Adam Sutcliffe, and Jonathan Karp have written excellent essays in the last few years.

In conclusion, Nelson's book is an extremely important contribution to the debate on the roots of modern political thought. In fact, this brilliant study in intellectual history questions some prominent elements of the conventional narrative of secularization and explores a topic crucial to understanding the evolution of Christian attitudes toward Judaism in the early modern era. Nelson's analysis will thus lead to a rethinking of the origins of some of the foundational political concepts of modernity, especially religious toleration, distributive justice, and civil equality, in light of the attention that a number of 16th- and 17th-century Christian scholars devoted to Jewish political and legal traditions. 